\title{
Lean Product Development Process with Design Verification Stages in the Value Stream of Automotive Industry
}

\author{
Fuat Ali Paker \\ Industrial Design Department of Istanbul Commerce University, Istanbul, Turkey \\ Email: apaker@ticaret.edu.tr
}

How to cite this paper: Paker, F.A. (2021) Lean Product Development Process with Design Verification Stages in the Value Stream of Automotive Industry. Journal of Transportation Technologies, 11, 37-60. https://doi.org/10.4236/jtts.2021.111003

Received: December 2, 2020

Accepted: December 28, 2020

Published: December 31, 2020

Copyright $\odot 2021$ by author(s) and Scientific Research Publishing Inc. This work is licensed under the Creative Commons Attribution International License (CC BY 4.0).

http://creativecommons.org/licenses/by/4.0/

\begin{abstract}
In the automotive industry, lean projects and innovation creation come to life by being updated under the control of systematic interdisciplinary process flows. The lean product development process that changes the shell, defined under the light of the variables created by the competitive conditions, is today measured by the value flow efficiency and the global market spread of the final product. Consequently, the lean product development approach, which aims to identify and purify all the wastes that do none value or create value to the system or cause burdens in the new product development process, is shaped by step-by-step approvals in the flow. In the main automotive industry company practices within the scope of the research ( 3 national, 3 international), the beginning of the concept of lean in design is to define and optimize the steps in the product development process under the value stream map. Therefore, the product function for which the customer has paid for, the function of the new product or the physical structure used to meet the needs in question, the comfort, life, experience, innovations of the scope that constitute the new product concept are planned and verified and implemented in the simplified automotive design stages at the beginning of the lean product development process. In this research, initial automotive design objectives and stages are at the focal point of the innovation and added value creation brought by the concept of "lean" approach. The research is modelled on the determination of steps that do not create added value together with the points where the flow circuits' or stems, the process is devalued, the interdisciplinary holistic studies intensify, the information and delay begin and end in the sequential and simultaneous design validation step transition stages, which are examined under the lean approach. As a visual and virtual tool that enables the elaboration of nominal values such as the total duration of the design ve-
\end{abstract}


rification stages and the influence of interdisciplinary stakeholders or the test level of the product design with the new product added, it reveals the value flow or losses. Hence research; from innovation creation and new product design steps, which constitute the initial stages of the lean product development process, to design verification analysis, the efficiency of the automotive company processes within the scope of the research has been measured by comparing using lean automotive design techniques, methods and concepts.

\section{Keywords}

Design Management, Design Verification, Automotive Design, Lean Product Development, Value Stream, Automotive Industry

\section{Introduction}

Computation of add-value creation that requires purification (Muda) and lean approach in each phase of the process of designing and developing new products in the automotive industry is revealed by the pure optimization of the design verification structure under the cause-effect relationship of defined basic stages [1] [2] [3]. Therefore, when focusing on value creation or conservation, the focus of lean process is; it lies under the purification of functions and equipment that the customer pays for, meets their functionally defined needs, meets the needs within the framework of comfort, environment and safety, or that the customer will not use in the product life cycle. The value stream map of lean product development that constitutes the design verification-oriented approach: the approach questioned throughout the basic design stages, which is essential for each new product piece, group and subsystem, includes the distinction of activities and parts that create or do not create added value [3] [4] [5] [6]. Therefore, in order to identify and reduce the waste resources in the product or process structure in all lean product development stages, the formation of a future case scenario contains the in-house up-to-date know-how archives in the holistic structure analysis where the value flow intersects with the design verification steps.

When the currents involved in the lean product development stages of the automotive industry, from the development of the product and process structure to the formation of the lean approach, are examined, sequential definitions and works are formed rather than design verification or value flow [7]. In the end of 18th century the focal spot developments of the product have been manufacturability for companies that have started mass production within the comfort and development of humanity (Figure 1). Half a century of competition fueled by world wars brought the concept of new, or best, newest product [7]. As shown in Figure 1, this period has created price-oriented main and sub-brands, national and international logistics systems, distribution, automation for mass and mass production, product manufacturing-oriented quality and sequential processes. Under the definition of the sequential phase that makes up the process within 
the framework of current situation analysis, global competition has formed the flow of product development simultaneously with the time-oriented co- operation of these stages (Figure 1). As shown in Figure 1, the development of new product-oriented process approaches in the manufacturing industry during the last century has been shown periodically.

As given in Figure 1, the lean product development process has focused on "innovation" and "feasibility" until today. Therefore, the expectations of the customer from the product, customer focus, the "value" or "price" that the customer gives to that product and that product function have come to the fore with economic developments today. "Lean Tools" in the value stream, therefore "lean management" in the final product, includes important interdisciplinary issues and approaches.

Under the researches of Womack (2002) and Liker (2011), it was developed by the lean institute association specifically for the automotive industry and spread in all industries [5] [6]. It is clear that the basic conditions of the lean approach, which is valid for almost every industry, are the new product functions to be offered to the consumer, the design quality, a sharp crossroads that will determine the future of automotive companies and therefore the level of macro nation-economies [8] [9]. Hence, "Lean product development" is applied under the principle of continuity of new product design within product development stages under a single or holistic approach, checkout in the final new vehicle structure, initial automotive design inputs, design-master stages, interdisciplinary design and engineering analyzes (CAE, CEA), life and physical road tests, design and development time, production (supply and assembly) and after-sales costs, experience and customer satisfaction, and it is a "purged" approach that does not contain any unnecessary processes and elements [10] [11].

\begin{tabular}{|c|c|c|c|c|c|}
\hline Phase & Period & Focus on & $\begin{array}{c}\text { Management of } \\
\text { Organization }\end{array}$ & Technology & Tools/ methods \\
\hline Industrial age & 1850 & -Specialization & -Functional Hierarchy & -Mechanization & Scientific management \\
\hline $\begin{array}{l}\text { Information } \\
\text { age }\end{array}$ & 1908 & $\begin{array}{l}\text {-Productivity } \\
\text { performance } \\
\text {-Cost reduction }\end{array}$ & $\begin{array}{l}\text {-Line production } \\
\text {-Orders/Controls }\end{array}$ & $\begin{array}{l}\text {-Serial Production } \\
\text {-Standardization } \\
\text {-Data Storage } \\
\end{array}$ & $\begin{array}{l}\text {-Specialise } \\
\text {-Financial Modeling }\end{array}$ \\
\hline $\begin{array}{l}\text { 1. wave: } \\
\text { Sequential } \\
\text { process }\end{array}$ & 1970 & $\begin{array}{l}\text {-Quality Management } \\
\text {-Continuous flow } \\
\text {-Task efficiency }\end{array}$ & $\begin{array}{l}\text {-Diversification of } \\
\text { companies } \\
\text {-Fusions and acquisitions }\end{array}$ & $\begin{array}{l}\text {-Automation } \\
\text { Information } \\
\text {-Technology } \\
\text { Management }\end{array}$ & $\begin{array}{l}\text {-TQM } \\
\text {-Statistical process } \\
\text { control } \\
\text {-Process Improvement } \\
\text { Methods } \\
\end{array}$ \\
\hline $\begin{array}{l}\text { 2. wave: } \\
\text { Concurrent } \\
\text { process }\end{array}$ & 1990 & $\begin{array}{l}\text {-Process Innovation } \\
\text {-Best practices } \\
\text { Better, Faster } \\
\text {-Business over the } \\
\text { internet }\end{array}$ & $\begin{array}{l}\text {-Flat organizations } \\
\text {-Value Added for } \\
\text { customers } \\
\text { operational excellence }\end{array}$ & $\begin{array}{l}\text {-Enterprise } \\
\text { Architecture } \\
\text {-ERP } \\
\text {-CRM } \\
\text {-Supply Chain } \\
\text { Management } \\
\end{array}$ & $\begin{array}{l}-\mathrm{ABC} \\
\text {-Six Sigma } \\
\text {-Process redesign } \\
\text {-Methods of } \\
\text { Reengineering }\end{array}$ \\
\hline $\begin{array}{l}\text { 3. wave: } \\
\text { Process } \\
\text { Management }\end{array}$ & 2000 & $\begin{array}{l}\text {-Evaluation Adaptability } \\
\text { Agility } \square\end{array}$ & $\begin{array}{l}\text {-Network-centric } \\
\text { organizations } \\
\text {-Hyper-competition }\end{array}$ & $\begin{array}{l}\text {-Enterprise } \\
\text {-Application } \\
\text { Integration } \\
\text {-Architecture oriented } \\
\text { on services } \\
\end{array}$ & $\begin{array}{l}-\mathrm{BSC} \square \\
\text {-BPM methods } \\
\text {-Outsourcing }\end{array}$ \\
\hline $\begin{array}{l}\text { 4. wave: } \\
\text { Lean Culture }\end{array}$ & 2010 & $\begin{array}{l}\text {-Continuous Change } \\
\text {-Value Management } \\
\text {-Dissipate } \\
\text {-Muda }\end{array}$ & $\begin{array}{l}\text {-Market growth } \\
\text {-Process effectiveness } \\
\text { before efficiency } \\
\text {-Poke-yoke } \\
\text {-Fix it right first time }\end{array}$ & $\begin{array}{l}\text {-Performance } \\
\text { Management } \\
\text { Software } \\
\text {-BPM Systems }\end{array}$ & $\begin{array}{l}\text {-Outsourcing } \\
\text {-Project field } \\
\text {-Communication } \\
\text { discipline } \\
\text {-A3 contact (Lean) }\end{array}$ \\
\hline
\end{tabular}

Figure 1. New product development trends in the automotive industry [7]. 
The advantages of lean product development can be listed as value follows [12]: 1) As the product development performance can be seen, with the increase in value innovation, the competitive power of automotive industry companies in terms of production, sales and profitability increases; 2) In basic development processes, the control of variable costs or the optimization of fixed quotation and most importantly, all of the design capabilities benefit especially in the sustainable development of innovation and decision-making mechanisms, with satisfactory results in development periods in terms of stage workloads, design responsibilities, vehicle safety or expenditure flow; 3) Along with the design processes suitable for mass production of automotive industry companies, it realizes new product and production integration transformation in technical innovation approaches and profitability in the development of after-sales parts or new functions; 4) In the systematic product development processes of automotive industry companies, the optimization of automotive design and scheduled engineering time is supported by questioning the radical value creation of stage-confirmation or verification (design verification) variables; 5) Along with the customer-oriented product, which is the goal of simplification, it is the cost-oriented efficiency created by the functions integrated into the product used by the customer, and even the privilege of obtaining the increasing product quality or reduction key process approaches.

The critical burble point or true origin, value creation and flow of lean product development are defined step by step, with an end customer focus. In order for the stage definitions in value creation to be meaningful, it is necessary to create an expression in a certain unit that meets the customer-oriented product-cost variables [5] [6].

\section{Lean Value Flow Map}

When the lean product development process in the automotive industry is examined within the scope of the research, determining and measuring the effect of variables that shape and shape the value flow on the final new product creates a holistic development structure for competitive manufacturing companies. Additionally, the lean product development process (protection of the value or value creation, value flow map, push or pull and excellence origin), which is developing in a conceptual structure, is evaluated under the approach formed by 5 main focus points [5] [6] [9] [10]. Accordingly, the orientation underlying the 5 centering approaches: the pecuniary or non-pecuniary end customer defines the value of the innovations on the new product and designs, develops and presents the value as a producer. Consequently, expressing the defined innovation in terms of a product that meets the needs of the customer at a certain time interval and under a certain charge-expenditure constitutes the integrated result of the aggregate value and composite value stream. Concurrently product development model, which continues to be implemented today, is defined as the development of push-pull systems, A3, Obea room, chief designer, kaizen, kan-ban and simi- 
lar process approaches and lean under the flow of value [5] [6]. In Figure 1, the main field of system integration according to the new product development flows up to the recent period and the customer demand structure, the collaboration-oriented lean and concurrently executed new product design structures based on the experience of stakeholders and project employees are presented [7]. In Figure 2, 7 fundaments 44 sub-principles have been put forward on the losses and protection of new design under the value stream with the Toyota lean product development research published by Liker in 2011 [6] [13]. In Figure 2, the foundations of the product development steps realized in the new era in a lean and virtual environment, along with the rapid development in software-specific design verification programs in the last decade, value flow and mapping studies in the field of application have been realized with the same pace [13]. As explained in Figure 2, the appearance of lean thinking, the value flow aimed at comparing the performance of global automotive industry companies in different continents under competition is based on a versatile research [1] [2] [5] [6] [13]. The value flow, which focuses on the flow of production and product development, concentrate on the flow of production and product development in automotive design processes, and the definition of "Lean" for global automotive companies, first dissemination with this research [3] [4] [5] [6]. Although lean thinking is defined in these sources as a part of the company culture along with the lean product development process, research and publications that provide dissemination related to the subject have intensified in the last decade.

In each box in Figure 2, the 7 basic principles that ensure the holistic flow of the lean product development process; the customer and market approach of the project (1), the use of the company's project and know-how standards (2), the communication structure that ensures the project flow (3), project phase stakeholders and step transition system (4), innovation approach and methods (5), employee and leader-manager culture (6), project and firm basic objectives (7) (Figure 2). Therefore, the lean product development approach is a holistic process flow with 7 basic perspectives in Figure 2. The 7 fundaments priorities in the value flow given in Figure 2 are structured on the activation of the traction (yoke) system in order to maintain the continuity of the product development stages that create value in the formation of the innovative function-part, then apply a repulse (poka) flow to all stages in order to eliminate the waste created by traditional product development steps and their drifts [13]. Therefore, Liker (2011): 1) Continuous improvement (Value Stream Mapping); 2) Standardization (KPI system); 3) Visual Management (Value Protection/Value Creating Area Detection/ Go to Gemba); 4) Flow and Pull principles (Demands for changes in design/ value); 5) Zero-Failure Principle (Product Development Towards Goals (Value Creation)); 6) Leadership and team definitions (Culture Change); 7) Frontloading of Information (Definition of design verification criteria), finally, it is to include continuous improvements in the system with the goal of excellence [6]. Linear value flow in lean 


\begin{tabular}{|c|c|c|}
\hline $\begin{array}{l}\text { 1. ContinuosImprovement } \\
\text {-Idea Management } \\
\text {-PDCA-Cycle } \\
\text {-Value StreamMapping } \\
\text {-Best PracticeSharing } \\
\text {-Benchmark } \\
\text {-Wikipedia } \\
\text {-Trade-offCurves } \\
\text {-Supplier CIP } \\
\end{array}$ & $\frac{\text { LEAN DEVELOPMENT }}{\text { PrinciplesandMethods }}$ & $\begin{array}{l}\text { 5. Zero-FailurePrinciple } \\
\text {-RequirementsEngineering } \\
\text {-QualityFunction Deployment } \\
\text {-Quality Gates } \\
\text {-Andon } \\
\text {-RapidPrototyping } \\
\text {-CardboardEngineering } \\
\text {-Systematic Problem Solving }\end{array}$ \\
\hline $\begin{array}{l}\text { 2. Standardization } \\
\text {-Processstandardization } \\
\text {-Workstandarts } \\
\text {-Categorization of projects } \\
\text {-Quotes of reuse of parts } \\
\text {-KPIsyatem }\end{array}$ & \multirow{2}{*}{$\begin{array}{l}\text { 4. FlowandPullPrinciple } \\
\text {-ProcessSynchronization } \\
\text {-Processoriented Project organization } \\
\text {-Competencecenters } \\
\text {-Regularcommunication } \\
\text {-SimmultaneousEngineering } \\
\text {-Supplier Integration } \\
\text {-Requestfor Design and Dev. Proposal } \\
\text {-Systematicsupplierselectionprocess }\end{array}$} & $\begin{array}{l}\text { 6. Leadershipand People } \\
\text {-Failureand No-BlameCulture } \\
\text {-Coaching } \\
\text {-Qualification Planning } \\
\text {-Mentoring } \\
\text {-LeadershipStandarts } \\
\text {-SpecialistCareers } \\
\text {-Strong ProjectLeader }\end{array}$ \\
\hline $\begin{array}{l}\text { 3. Visual Management } \\
\text {-Visualization of Project contents } \\
\text {-Visualizationbetweenareas } \\
\text {-Go-to-Gemba } \\
-5 \mathrm{~S} \\
\text {-Project Monitoring }\end{array}$ & & $\begin{array}{l}\text { 7. Frontloading } \\
\text {-Optimization of portfolio } \\
\text {-TargetCosting } \\
\text {-Life Cycle Planning } \\
\text {-Set-basedEngineering }\end{array}$ \\
\hline
\end{tabular}

Figure 2. Lean product development process principles [13].

product development is initially formulated by systematic data collection and data analysis, creating unit value and constituting a basis for connections. The front end of lean product development process in determining the metric unit in which each discipline or function is accepted; it is the most important input for determining the scale and calculation of losses in the value stream map.

Lean product development renewal plan consists of four basic stages: research, design, validation and development. In the value flow presented in Figure 3, two different approaches are used to define lean product development; the adaptation of lean product development principles to the product development process under the value stream (Flow and pull system) or the elimination of consume in the product development system (value stream map) are methods and approaches used to ensure flow [6]. As can be seen in Figure 3, squander away is defined in the product development process under the design verification phase transitions and the prevention of cycle or work cost that does not add value, a value map for simplification and a value chain are defined. Today, automotive products design concepts and new product development processes, which are at the centering of competition, include innovation-based approaches. As expressed in Figure 3, the concept of new product is a very comprehensive term that includes: pure-stock new product, improved new product, modified new product [6].

As explained in Figure 3, lean product development is a long and complex structure full of risks that the company undertakes to create a new vehicle design. This main and sub-new product-based structure is affected both by external environmental factors that the company uncontrolled, and by internal cognitive processes [6] [14]. In the severe global fierce competition environment, automotive main companies can acceptable level of risk by reducing the 


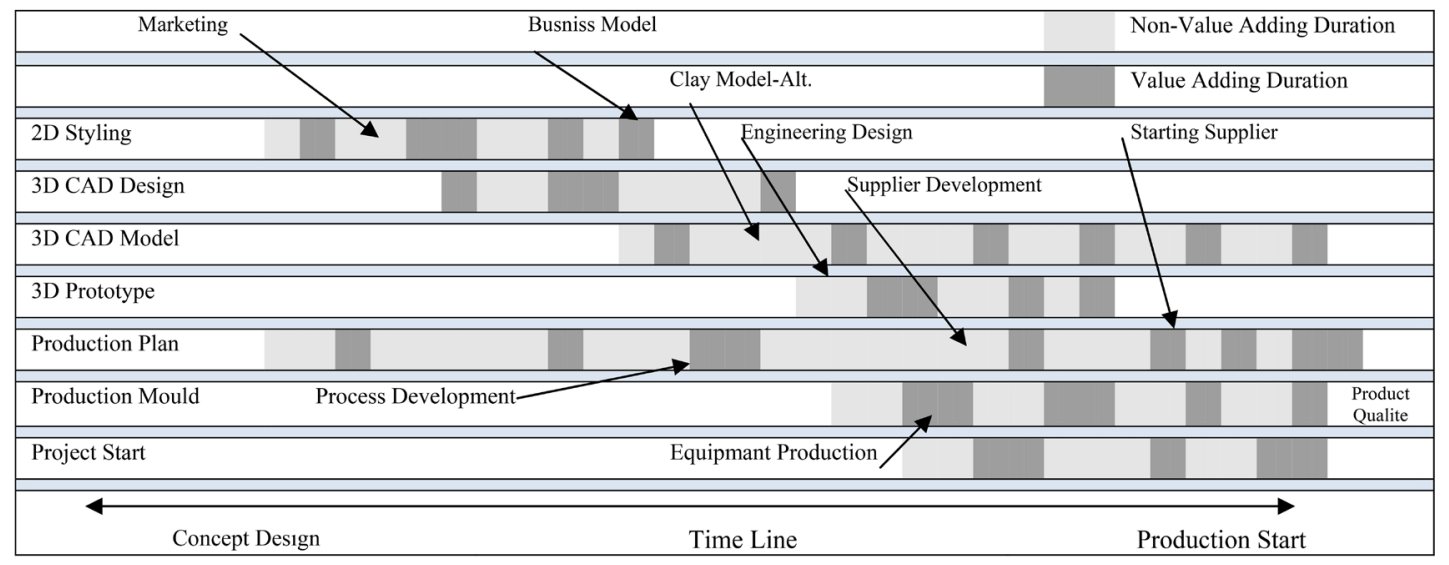

Figure 3. Value chain of automotive design flow in lean product development [6].

uncertainties in the market success and deployment of the new product with the hierarchical stage assembly at different phase of the new product design and lean development process.

\subsection{Key Features of Value Stream Map}

Simplifying the entire process in a sustainable, iterative (updating its own development) structure with the design verification clearance steps under the value flow and ensuring dissemination in company functions comes to the fore under the formation of chief design managers and expert improvement project teams with a lean culture. The first product development process step in which simplification is initiated is the automotive design stage, where the design verification pre-knowledge is transferred, where innovations occur. The core process in question, the particles and the holistic formation of the fundamental structure support the lean approach, and include defined problem-solving methods and detailed measurements under metric units [14] [15]. The sub-sets, which make up the company management and product development departments, set up a clean and self-directed communication that includes lean project parameters and cost (timeline plan and workload) oriented flow information. Therefore, product development and automotive design phase transition measurements performed under lean tools are used in the installation or updating of design verification steps according to the improvement roadmap. In addition to the lean product development process improvements, management opinions and expertise reports of all departments are evaluated in a result-oriented manner. In addition, a dynamic interaction method is used, which includes the development of automotive design processes, which are the focus of lean product development studies, and visual communication (obea project room, A4 communication, etc.) that all departments can follow [6]. This interaction reflects instant changes and updates to all project employees instantly. Additionally, link is established between team members, value stream, lean tools, lean metrics and customer demand priorities for an integrated circuit to lean product development processes. 


\subsection{Fundamental Structure of Value Stream}

Sustainable leaning modeled under the value stream ensures the continuity and cycle of development up to production by revealing the link or formula between the new product and new product development and design processes. In the new product development process, "value creation" and "value conservation" consist of eight fundamental flow steps [6] [7] [13] [14]. Therefore, these are: 1) Lean/culture; 2) Value flow decision/choice; 3) Lean deployment/learning; 4) Current situation analysis/map; 5) Lean metrics/unit; 6) Best-case future scenario/synthesis; 7) Kaizen plan/prediction h-Kaizen plan/application. The value stream revealed by the design verification or stage approval models the lean product development management as well as the simplification of all automotive design activities of automotive industry companies. The fact that any smallest structure in the organization understands the concepts of simplification and directs the business processes in this direction is the additional indicator of the internalization of the cycle in question. Therefore, simplification enables value-oriented (metric unit) control of the steps in the flow of all new product development and automotive design activities or the design verification phase transition approval processes.

\section{Value Flow-Map}

It focuses on leaner in new product development processes, purification and elimination of disciplines that provide new products and development or consume that does not add-value in interdisciplinary activities. When the definition of value is examined, it is seen as the whole of the design activities that the customer pays for, pays for it, and that will bring the innovative transformation and functions of the new product to life-cycle. Therefore, work out the cost of; virtual or physical testing, verification, advertising, training, production-stock, material-stock, discard, rework, inventory, over-processing or control, approval and similar transactions are calculated under value creation and find their equivalent. The immediate cause and effect relationship of the consume in the formation of innovations that the customer does not use or new product functions that they are not aware of is examined in depth as a whole. Additionally, functions, values or studies that do not appear to be result-oriented on this final new product constitute waste. These studies, which are included in the process of designing and developing new products, constitute the 'lean values' that need to be studied for the new product-oriented formation reasons of these variables. However, in the retainable lean approach, it is a priority for a sustainable cycle to identify the root causes of consumes and to find these track-out points in the new product development process before eliminating waste generation. Principally, the lean approach in the automotive sector is destroyed under the result-oriented metric value together with the stages it depends on when the root cause of consume is identified. Therefore, fundamentally all automotive design activities and new product development processes or disciplines flow within the 
framework of retrospective lean approach, with design verification phase transitions, by determining the preferred metric "value" perceived by the customer on the new product. This approach maps the incremental value stream and creates the result-oriented metric effect weights of the lean product development steps. The value stream or map defines the innovation output and innovation conservation step by step in the lean product development process, scaling the step transitions together with the basic disciplines and interdisciplinary studies. Therefore, it develops and improves "lean future-case flow" in places where value flows in the design and development process of innovation, or in disciplinary or interdisciplinary phase transitions, which are stagnation and accumulation in the process. On the flipside, this diagnostic approach constitutes the "Flow and pull principle" in lean product development. The process-oriented emergence of innovation on the new product perceived by the customer and its inclusion on the final new product come into play under the flow-pull system, under the lean structuring of the new product development process. It is the activation of the "poke (flow-push) system" for the design verification detail definitions at the recirculating cycle points that form the flow-cycle after the installation of the flow-pull (yoke) system or during the phase transitions, after the first stage of sustainable leaning in the automotive design and development processes of the new vehicles product. The verification of the lean product development process under the innovation-oriented design poke system is modeled according to the comparative results of poke-yoke systems, measuring for "new future-situation flow" or "sustainable perfection" [5] [6] [14] [15]. In the lean product development process, the innovation and design-oriented value flow is not only under the structuring of individual stages, disciplines or interdisciplinary steps, but according to the formation of innovation on the new product and the articulation of innovation to the final new product, the whole process is reviewed and improved.

Therefore, the field study of the research was discussed in terms of comparative automotive design flows at the local (LC) and global (GC) key company level of the new and lean future case applications in lean product development processes in the automotive industry. The flow variables that make up the comparative structure in the sample in question are questioned under the final regional "market share ratios" of the "minibus" product designed under competition by " 6 automotive industry companies" participating in the research. Consequently, in the process of new vehicle product design and development, the map of the customer or innovation-oriented value flow, from the customer to the development process, by following the innovation formation path of the product, each discipline in the lean diffraction, each interdisciplinary design verification transition step, is examined in-depth, to each participating automotive company in the comparison specially evaluated. In the second stage of the study, the "future situation" map, which shows how the process should flow by asking a number of critical key questions, is presented specifically for the company in the 
comparison structure [16] [17]. Lean product development process practices, which are included in the comparative structure of 6 automotive industry key companies included in the field study, are divided into two components in the value stream: all new product development flow disciplines and interdisciplinary phase transitions where design validation takes place are detailed [17] [18] [19]. In lean product development, all activities of the design and innovation value stream that do not create value are determined and purified from the process [14] [19].

In the heavily competitive automotive industry, determining the effect of innovation acquisition value, the conservation in the design and product development process flow or the transfer of the result to the new product, from a single stage in the lean product development process (market or customer research, design, design verification, testing, development, etc.) lend assist to see more. The mapping of the current flow in question reveals not only the wastefulness but also the consume sources in the step by step value flow paths. Therefore, this provides the formation of a common metric unit of measurement or platform and spoken language covering all functions of the company, from design to production. As the flow-related scale that forms the comparative structure in the study is visible, result-oriented retrospective analysis and synthesis create a supportive roadmap (Figure 4). Otherwise, many findings and occurrences taken from the research field constitute values outside the detail comparison structure. The example in Figure 4 connects new definitions and concepts specific to each firm in the field study of the research with techniques under the one on one interview and data envelopment method [20] [21] [22]. As can be seen in Figure 4, the new product development process consists of 6 fundamental stages. These 6 basic stages define the relevant activities and time simultaneously (Figure 4).

In the figure above, product development stages are given with letter codes, $\mathrm{A}$, $\mathrm{B}, \mathrm{C}$, etc., while the durations of these stages are given in numbers (times in months) in the next step after the letter code (Figure 4). In the example given in Figure 4; design verification (E) studies take 18 months between the "C" stage and "F" stages. Therefore, the work-time-oriented process creates a structure with a total time of 48 months and a co-work flow, as can be seen in Figure 4. This timeline and job oriented process development is the key concept of the development of competition in all sectors in the process of new product development. Therefore, when the variables in the subject-specific application area are examined, the steps and sub-design stages involved in the new product development process are investigated step by step, and their flow-oriented effects are investigated in the studies of Eppinger (2012), Ulrich (2015), Ullah (2016), [21] [23] [25]. In his study, Ulrich (2015) made comparisons in different sectors on the variables and durations involved in the phase transitions, while defining the new product development phases consecutively [24]. Ulrich (2015) and Eppinger (2012) stated in their studies: Until the 1990s, the product realization function concentrated on the manufacturing stages, and after the 2000s, it 


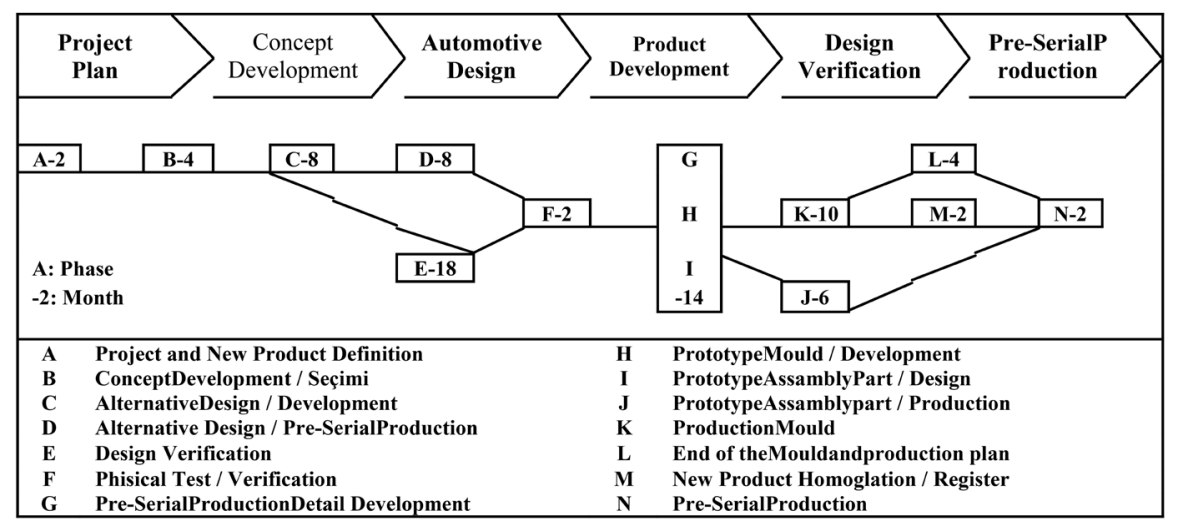

Figure 4. The duration of the design stages in the product development [15] [23].

turned to lean-oriented structures under competition [21] [24]. In Figure 5, in the study of Ullah (2016), in addition to the investigations of Ulrich in the product development process until 2015, he listed the variables affecting the subject and compared the gains in different industries in the same table [24].

As can be seen in Figure 5; number of product development employees and duration, number of product parts, product life-cycle time, project cost or results, similar factors constitutes the comparable structure variables of the basic process. In Figure 5, when the structure and gains affected by the new product development process are viewed on a sector basis, they constitute approaches worth studying [24]. Therefore, the fact that the research is carried out in different company structures in the same sector, with different leaning results will result in results-oriented principles in practice. Also in his research, Ulrich, In the 1970-80's, the first period of sequential step operations, in the second period of $1980-90$ 's, it took a parallel phase transition with the formation of business groups, and that the process stakeholders have a simultaneous flow under the common job descriptions in the last period 2000-10, finally, he stated that in the years 2010-20, the process began to simplify with all its stakeholders and duties [24].

\section{The Implementation of Findings}

In the research, under the competition created by the regional market, the design and lean product development processes of 6 automotive industry companies (3 global companies (GC) and 3 local companies (LC)) manufacturing vehicles in the same class were defined specifically for each company within the framework of the value flow mapping, common AHP (Analytic Hierarchy Process) mathematical model analysis was applied to compare the structure (Figure 6). The fact that the 6 automotive industry companies participating in the study have been operating in the area with defined boundaries for more than fifty years, as well as being the world's leading vehicle developer and manufacturer, describes the importance of the economic dimension of the study together with the severe competitive conditions [1] [2] [3]. In terms of production 


\begin{tabular}{|l|c|c|c|c|c|}
\hline & \multicolumn{5}{|c|}{ New Product Development Value } \\
\cline { 2 - 6 } & $\begin{array}{c}\text { Hand-Tool } \\
\text { (Stanley) }\end{array}$ & $\begin{array}{c}\text { Skate } \\
\text { (Rollerblade) }\end{array}$ & $\begin{array}{c}\text { Printer } \\
\text { (HP) }\end{array}$ & $\begin{array}{c}\text { Automotive } \\
\text { (BeetleVW) }\end{array}$ & $\begin{array}{c}\text { Airplane } \\
\text { (B777 Boeing) }\end{array}$ \\
\hline ProductionAmount- Year & 100.000 & 100.000 & 4 milyon & 100.000 & 50 \\
\hline New Product Life Cycle- Year & 40 & 3 & 2 & 6 & 30 \\
\hline Product Marketing Price-\$ & 6 & 200 & 130 & 20.000 & 200 milyon \\
\hline New Product PartUnit & 3 & 35 & 200 & 10.000 & 130.000 \\
\hline New Project Duration- Month & 12 & 24 & 18 & 42 & 54 \\
\hline Product Development Personal & 3 & 5 & 100 & 800 & 6.800 \\
\hline Product Development Supplier & 3 & 10 & 75 & 800 & 10.000 \\
\hline Product Development Value-\$ & 150.000 & 750.000 & 50 milyon & 400 milyon & 3 milyar \\
\hline Production Value- \$ & 150.000 & 1 million & 25 million & 500 million & 3 billion \\
\hline
\end{tabular}

Figure 5. Product development variables across different industries [24].

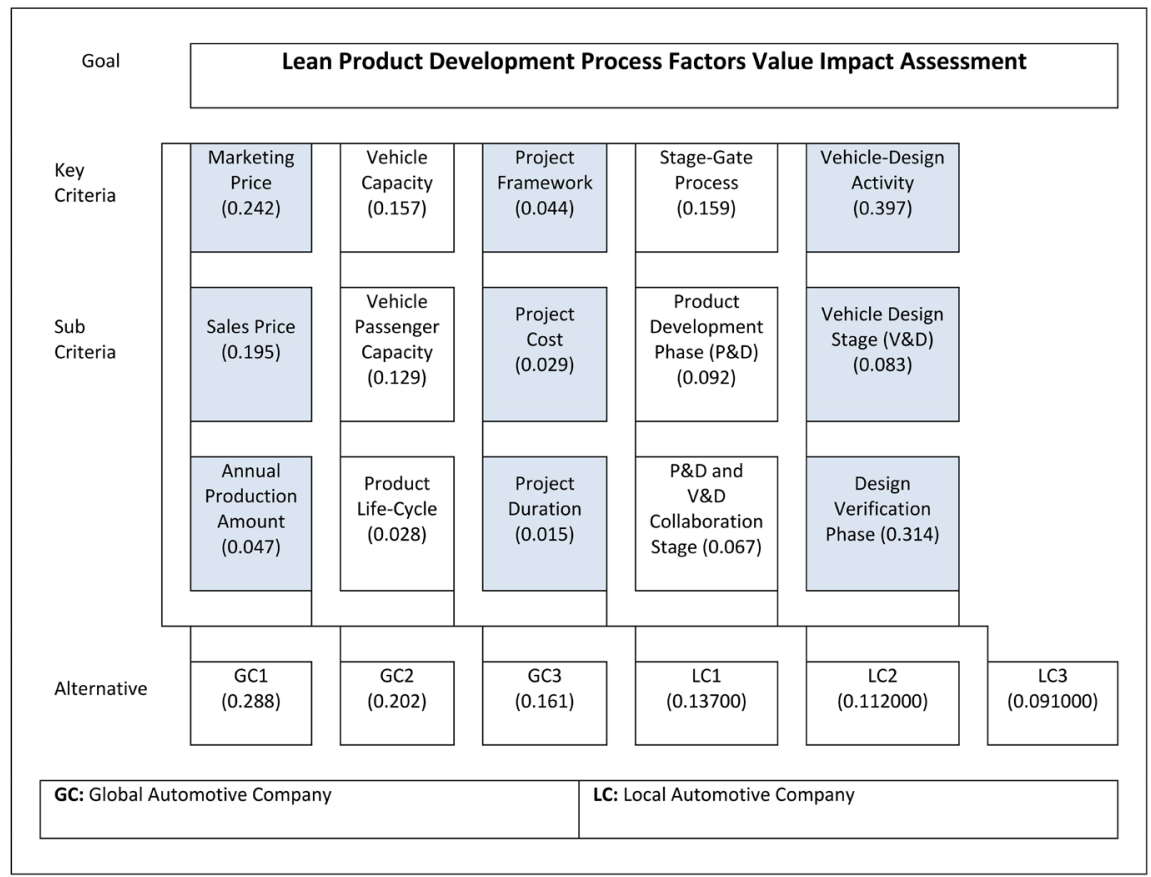

Figure 6. AHP comparison lean development matrix, main and sub-criteria [1].

numbers, developments in the region that constitutes the field study of the research and specific to commercial vehicles in the world are statistically reported by the OSD (automotive industry association) [26]. 3 local (LC), 3 global (GC), 6 automotive companies, which are in the 12th place in the world commercial vehicle market and share a significant market share, link their market share developments to these and similar academic studies jointly.

In Figure 6, 6 automotive manufacturing companies in the AHP mathematical model structure with defined main and sub criteria form alternatives under competition [1]. The above-mentioned mathematical model consists of 5 main-comparison criteria; lean product development process steps, joint activities, design phases, design verification phase transitions, project time, project cost, vehicle performance/ capacity, sales price, product life cycle, annual manufacturing quantity constitute the 10 sub-comparison criteria in the value stream. In the model in Figure 6, the value stream of GC1 with the highest market share and manufacturing is mapped comparatively, while the lower limit is comparatively compared to the LC3 firm with the lowest rates. Following the 2007, 2012, 
2017 crises affecting the automotive industry and the last global pandemic and economic crises in 2020, competition forums forming university-industry cooperation with government support, the establishment of high quality R\&D infrastructure for mass automotive production, has reached a level of discussion after the 2000's. In Figure 6, the AHP mathematical model was created, the application area selection in 2014-19: It started with the design verification and all design activities in the lean product development processes under the value flow of the automotive companies in our country. The preliminary preparation phase included in the theoretical proposal of the research has created a field structure suitable for the one on one interview study. The framework of the research that constitutes this article is the limits for in-depth knowledge formation in a narrow field: international main brand-dependent companies (GC) in the local automotive industry and the company that continues its new product development activities to create a global main brand (LC) in the national automotive industry with its establishment in the 1960s. It includes in-depth studies on the value stream with its employees (Figure 6). While this approach enriched the research, it created the opportunity to examine the perspective in depth by comparing the systemic differences of the two different constructions (GC and LC) in the value stream (Figure 6). Measuring the impact of the new vehicle's emerging innovations or differences on the value stream, up to mass production studies, has important consequences for lean process development. It is possible to examine the flow in question step by step, by evaluating the qualitative and quantitative findings together throughout the research. In addition, one on one interviews, which constitute the quantitative part of the research, have revealed that the whole product development process is tested in the field where it is applied according to value creation and preservation, and the results that affect the company within the scope of the value stream are effective factors in the leaner operation. Therefore, each feature of the vehicle product in the comparative analysis structure under one on one interviews, together with the national and international automotive industry association reports, the experts working in each value stage in the field of application; the lean product development stages were determined within the scope of the findings on the value stream mapping scale, where the role, task, profession, software, hardware, time and gradual cooperation were in cooperation (Figure 7).

Figure 7 , one on one interviews conducted by the automotive industry company in the field of application of new product development activities (the last 5 criteria), the proportional results of the effect of lean on the final product and the differences in operation, quantitative values are revealed by in-depth examinations (first 5 criteria) from automotive industry reports or statistics. It is important for the development of the automotive industry to verify the quantitative study findings included in the structural comparison analysis created by one on one interviews with qualitative market data and to measure again tomorrow with the use of the resulting information today (Figure 7). 


\begin{tabular}{|l|c|c|c|}
\hline \multicolumn{1}{|c|}{ Global Automotive Company (GC) } & GC1 & GC2 & GC3 \\
\hline Vehicle Class & M3-Minibus & M3-Minibus & M3-Minibus \\
\hline Vehicle Marketing Price - TL & 95.000 & 90.000 & 85.000 \\
\hline Production Amount - Year & 36.000 & 5.498 & 2.642 \\
\hline Vehicle passanger capacity - Seat + Stood & $16+6$ & $14+4$ & 12 Koltuk \\
\hline New Product Life Cycle - Year & 5 & 6 & 8 \\
\hline Project Duration - Month & 48 & 47 & 48 \\
\hline Automotive Design Duration - Month & 24 & 23 & 24 \\
\hline Lean Product Development Process - Personal / Phase & $1.300 / 24$ & $800 / 20$ & $270 / 16$ \\
\hline Design Verification - Phase Local Automotive Company (LC) & 7 & 6 & 4 \\
\hline & LC1 & LC2 & LC3 \\
\hline Vehicle Class & M3-Minibus & M3-Minibus & M3-Minibus \\
\hline Vehicle Marketing Price - TL & 150.000 & 120.000 & 110.000 \\
\hline Production Amount - Year & 7.000 & 5.000 & 2.100 \\
\hline Vehicle passanger capacity - Seat + Stood & $18+8$ & $16+6$ & $14+4$ \\
\hline New Product Life Cycle - Year & 10 & 12 & 14 \\
\hline Project Duration - Month & 24 & 23 & 24 \\
\hline Automotive Design Duration - Month & 12 & 13 & 12 \\
\hline Lean Product Development Process - Personal / Phase & $72 / 12$ & $60 / 10$ & $40 / 8$ \\
\hline Design Verification - Phase & 4 & 2 & 1 \\
\hline
\end{tabular}

Figure 7. AHP comparison of lean product development process and vehicle [1].

\subsection{The Implementation of Findings: LC Automotive Companies}

According to the design verification step transitions listed in Figure 8 through mutual interviews with 30 executives from 3 local (LC) automotive industry companies, the lean product development stages constitute the current value flow, process matrix in the annex. When the lean product development expertise of LC companies, which has a common relationship with the design verification phase transition processes, it was observed that the structural analysis (CAE) and fluid mechanics (CEA) step formed a recurring cooperation in the later stages of the value stream (Figure 8). It was revealed in one on one interview with the company and lean product development managers that LC companies have just started to incorporate the structural engineering analysis of vehicle constructions in the computer environment. Under the project goals of the sales and marketing department of the LC managers, the lean product development stages that include $2 \mathrm{D}$ sketching, presentation of conceptual alternatives, $3 \mathrm{D}$ CAD model, prototype manufacturing, automotive design activities that form the step flow: project and cost management, motorized chassis and body, structural analysis, electronic systems, after-sales, testing, certification and similar steps, it was determined that the value flow continues simultaneously (Figure 8). Another common approach of LC managers: their lean product development expertise and design verification phase transition definitions, hence they are just starting to create the value stream map. During one on one interviews of LC, participant company managers, who were asked to draw the lean product development process or value flow by hand, stated that the basic expertise that should be present is not in their companies, and they are thinking of starting a study in order to improve the 12-step lean product development processes (Figure 8). In Figure 8, the lean product development process and the common stages that create cooperation in the value stream are illustrated by the participants as a sketch by hand during one on one interviews and controlled according to the field study results.

For the new minibus vehicle project, LC company executives stated that the works involving international specification adaptations that come into operation 


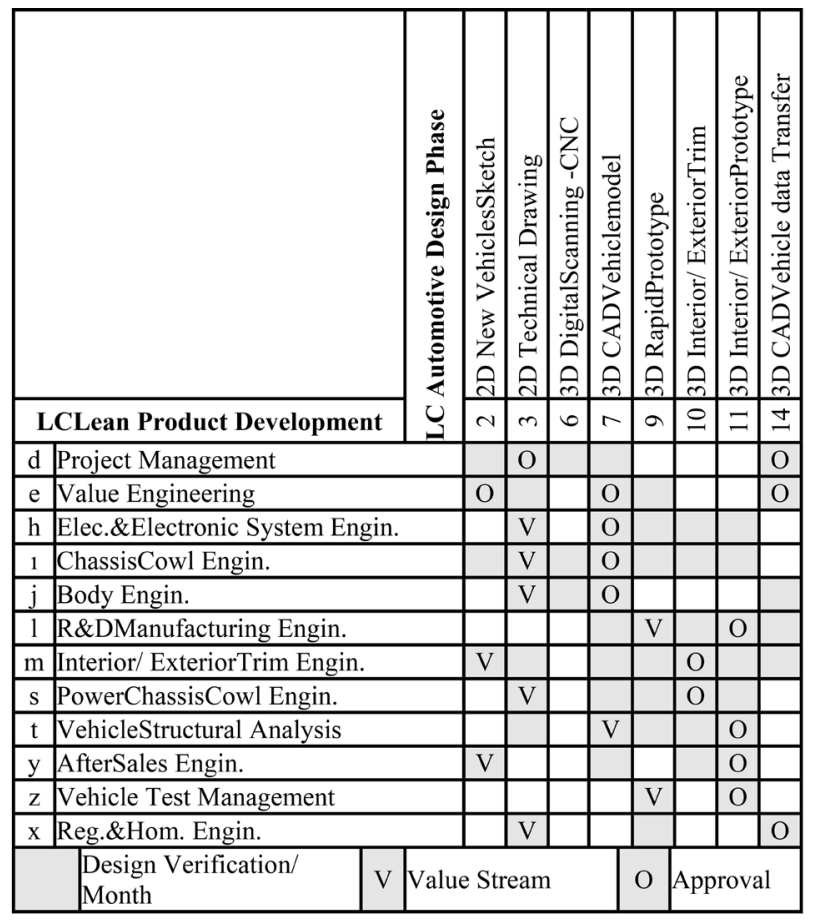

Figure 8. LC automotive companies lean product development in the value stream.

with the new projects and market targets of the existing vehicles of this class are carried out under the value stream and lean (Figure 8). In addition, within the scope of the new minibus project, during the adaptation of the new regulation values to the vehicle, it is revealed that lean product development engineers (lean consultant) and design verification analyzes play a role in the value stream in close cooperation (Figure 8). LC automotive industry company managers stated that under the $2 \mathrm{D}$ conceptual sketching studies included in the beginning of the new project, they focused on the design differences of the current production vehicle, along with the competing products, and made the new product both preferred and simplified under the value stream. Therefore, LC company executives emphasized that the development process of the new minibus product is continued under the modifications led by lean work on the 3D CAD model, which is formed as a result of the design verification phase transition approvals. In this context, it emerges that the development process of the new minibus product, along with the design verification steps, is more intense in the value stream after the 3D CAD model phase. In addition, it becomes clear that lean studies in local LC automotive companies are seen as a function added later instead of defining or creating or improving a value stream. The lean product development process is described in Figure 8 in the light of the responses of the managers within the scope of the one-to-one meetings of the LC companies. LC automotive company executives have introduced common interdisciplinary cooperation definitions over the value stream draft of the automotive design and lean product development stages listed within the framework of mutual inter- 
views (Figure 8). In addition, the knowledge that the project management team was established at the preliminary stage of the new vehicle development, under the guidance of the company's senior management, leads to the conclusion that the step definitions and criteria in the value stream are position-oriented rather than product. Therefore, during the lean product development period, it is revealed that there is no value flow related to the said value creation and preservation provided by the project management team, which is focused on the management position in the company, rather than the product knowledge. LC2 company managers, who are involved in the details of this approach, underlined that the new product-oriented project management consists of friends who have previously managed finance, purchasing, quality or manufacturing departments and that they have the experience and knowledge to direct the process. It was stated that the LC2 automotive company managers, new minibus or project targets progress under the leadership of the said process manager under the meetings held specifically for the sales and marketing department (Figure 8). In addition, LC3 company executives informed that, as seen in Figure 8, they collaborate on each step of the 8 automotive design steps that match the value stream with the lean product development stages consisting of 12 stages. It has been observed that the LC group automotive industry companies, whose value flow is examined in Figure 8, have turned to design verification transition steps for value creation and protection in their lean product development processes. Of the total 14,100 minibus products produced annually by LC companies, approximately 10,000 of them are exported and 4100 units spread to the domestic market. Here, in the lean product development process, where the value flow is examined, it has been determined that 6 design verification steps and 9 common steps provide value creation or gain intensity in the value stream. In practice, the time variable, which is of great importance in terms of the simplification of the cost, the fact that the stages are at half the value compared to the global automotive industry companies' due to the missing or not used, the new product created with insufficient information leads to losses instead of gains in the market spread.

\subsection{The Implementation of Findings: GC Automotive Companies}

Under the light of one on one interviews with 30 company executives from global automotive industry companies (GC) within the boundaries of the research, first of all, the value map of the current situation in the lean product development process was presented with the existing data regarding the current product, new product, customer, market, production and value flow. The scope determined under the minibus product family subject to the case study creates heavy competition in the development and market of the commercial vehicle product for passenger transportation in the research field. The minibus automotive product, which plays a dominant role in international markets, is designed, developed and mass produced within the limits of research. New and lean prod- 
uct formation or testing, value flow in lean product development with a definition, has been examined in detail under the current processes of 3 different global automotive industry companies (GC) participating in the research. In order to compare the similarities or differences of value flow under a common structure, automotive design and design verification phase transition steps that match the lean product development steps are evaluated, and the cross-relationship matrix representation is conveyed in the research (Figure 9). During one on one interview, managers were asked to draw manually according to the value flow system under the development process of the minibus product of GC companies.

During their mutual meetings with GC automotive company participants, the value flow drawn by the executives as a sketch by hand and supported by the questions is given in Figure 9 as a table. Among the GC automotive industry companies within the scope of the research, a product development team of 1300 people, a total of 9500 employees, companies with a daily production of 1000 vehicles or more or with lean product development processes that are updated played a leading role in the study. The development process of the new minibus product, which is based on the common responses given by the GC company participants, which are included in the study and has a more defined development process compared to LC companies, has been compared within the framework of the value flow, according to the design verification phase transitions and initial design steps in Figure 9. The value flow in the lean development stages of the minibus product, which was formed with the common answers and hand drawings of GC company participants created under the same common base, was again structured and evaluated in Figure 9. It has been confirmed under one on one interviews that the lean product development flow in GC automotive industry companies takes 48 months, the first 24 -month period is carried out with the project start-up design stages and intensive design verification step transition studies, although it is included in the findings of the interviews (Figure 9).

On the other hand, another factor that is common in the value stream of GC automotive industry companies is the defined presence of the preliminary stages that form the customer and market research, which are at the beginning of the project (Figure 9). The value stream includes studies where the design goals of the new project in question are determined, definitions are formed in value creation, global or regional new specifications and technology adaptation decisions of these preliminary stages and the countries where the new product will be sold are determined (Figure 9). As can be seen in Figure 9: regional vehicle management, strategic project management and new technology adaptation stages match the stages that direct the value flow in lean product development steps, provide value creation or value preservation, and form design verification step-by-step approval presentations. In Figure 9, regional vehicle management, vehicle architecture and new technology adaptation stages observed in the processes of GC automotive industry companies are included in the value flow 


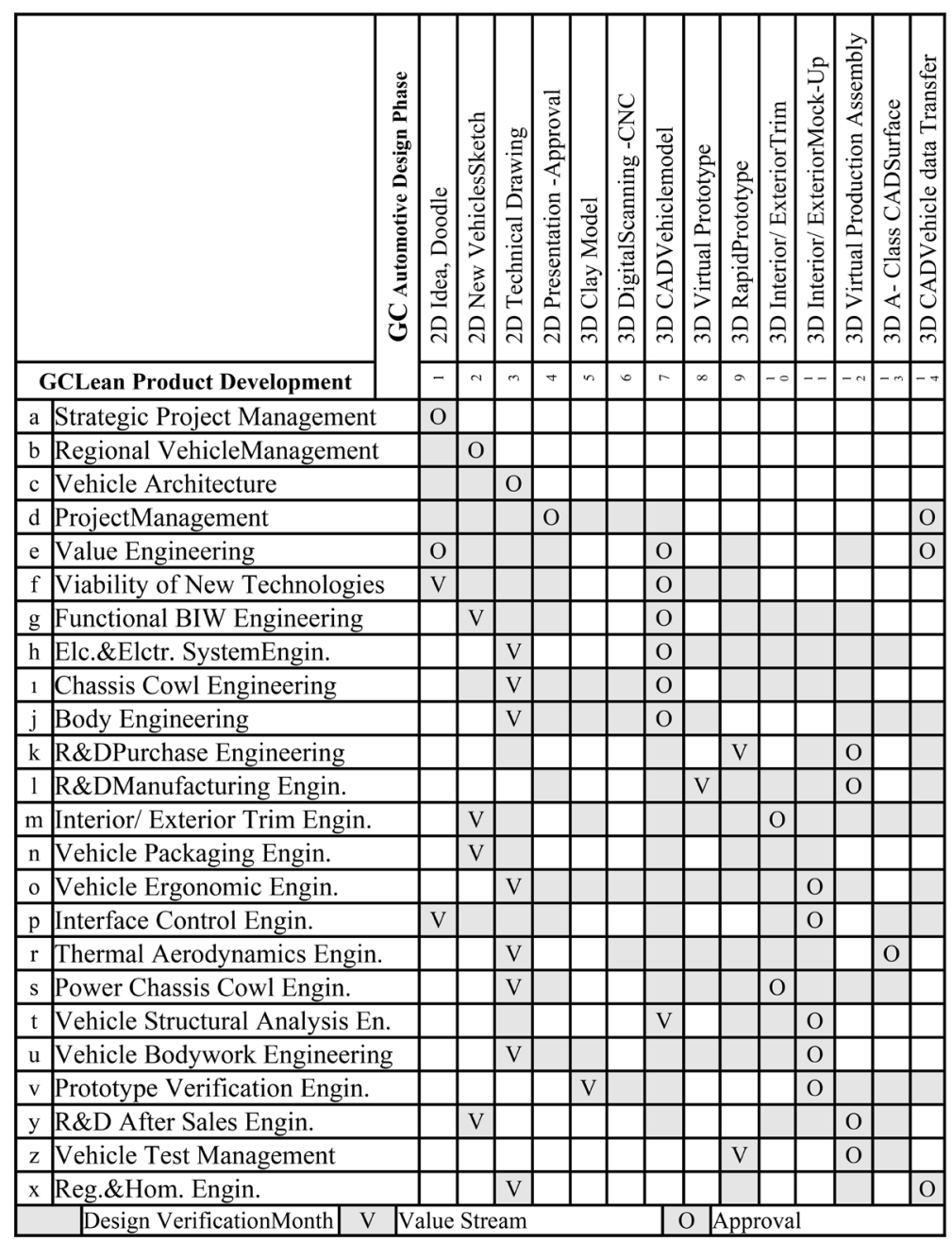

Figure 9. GC automotive companies lean product development in the value stream.

of LC companies in a single stage as project management. On the other hand, while 12 lean product development stages of LC companies and 8 automotive design stages are matched in Figure 8, in Figure 9, 24 lean product development stages and 14 automotive design and design verification stages are matched in Figure 9. In the same time interval, the need for intensive communication and cooperation with human resources, software, hardware, and knowledge to carry out more stages is revealed in the value stream mapping of GC company interviews (Figure 9). In one-on-one meetings with GC automotive industry company executives; in order to turn alternative $2 \mathrm{D}$ conceptual sketches and clay models into 3D CAD computer models, the value flow created by modifications based on simple and guiding surface analysis or calculations is revealed (Figure 9). It was observed within the framework of the interviews that the design verification studies, which started with the $2 \mathrm{D}$ conceptual sketching in the automotive design stages and the transformation of the information into the computer environment into 3D CAD model data, continued under value conservation throughout the entire product development period within the scope of value 
creation with structural modifications in line with the project objectives (Figure 9). Automotive design and lean product development process management in GC companies: while working with the marketing team to determine market or customer targets in the value stream, on the other hand, to control the communicative dimension of the cross-linked parts of the vehicle development stages in order to ensure the healthy life of the new project for value preservation. In addition, they started the new minibus product project with market research, collected detailed information about the constraints, opportunities, requirements or requests by making mutual meetings with the product architecture and feasibility teams of the foreign main brand center they are affiliated with, and collecting these data together with lean product development management, and it was stated that each phase was discussed in transition approvals (Figure 9).

\section{Comparative Current and Future Situation Value Mapping}

The positive impact of the automotive design steps that affect the value creation in the value stream in the lean product development process of GC and LC automotive industry companies within the scope of the research stand out as interdisciplinary design verification activities on the scale of repetitive modifications and phase transition limit values. Therefore, by matching with the results of interdisciplinary software, hardware, professions, durations, market dissemination in the lean product development steps in cooperation with automotive design revealed in mutual interviews with GC automotive company managers, the efficiency measurement of value creation or conservation and the value flow to the whole stages and its effect occurs at the firm level. In addition, as planned in the study, the value flow results from mutual interviews are tested with a case study focused on the new minibus product project and market spread results. In Figure 10, AHP fuzzy logic method has been used to measure how all the value flow findings revealed in the field research results have a positive effect on the new product (the effect of lean product development stages on the value flow). Under competitive conditions specific to the automotive sector, modeling of the value stream and the contribution rate of the process structure, which has a positive effect on lean product development, to the final new product and innovation, together with the AHP mathematical model analysis, where the automotive industry market results are also evaluated (Figure 10). The effect of the product development step in each value stream revealed in the research on the whole, analysis with fuzzy logic method creates a new approach for the development of the vehicle industry (Figure 10).

In Figure 10, as a result of in-depth examinations made in GC and LC automotive industry companies using the data envelopment method, it is predicted that basic improvements can be made in the value stream. The fundamental process in which the project goals are formed and designed is "value creation"; the design verification steps, which form the application testing studies, constitute the secondary main process, namely "value preservation". By defining these two 


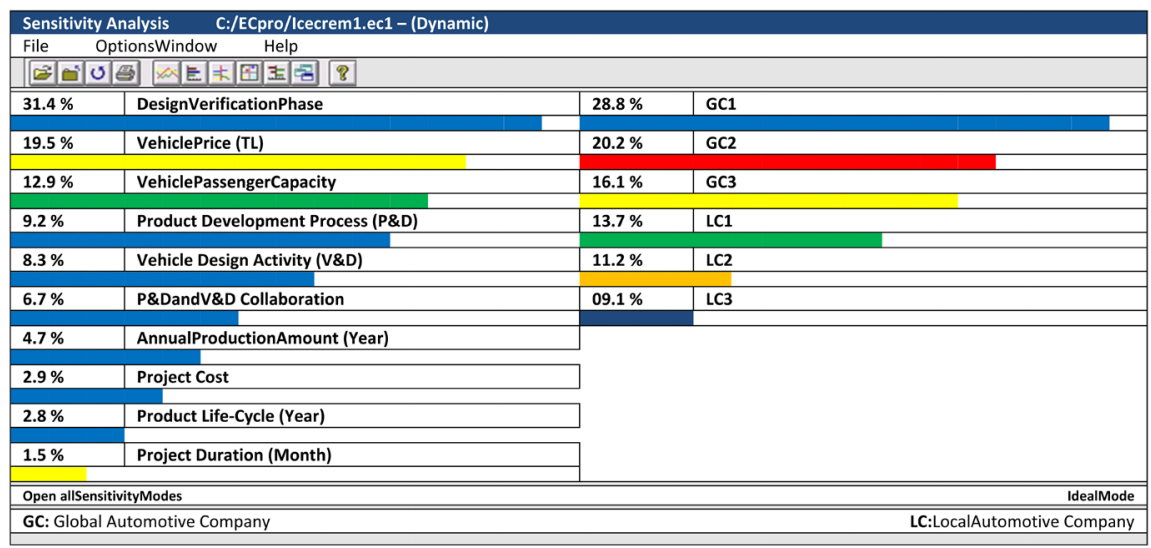

Figure 10. Product development engineering in cooperation with design stages.

independent main processes in a formation that will provide value creation in an interdependent manner, an effect that will positively support the value flow can be created. While value creation, which constitutes the first main process in question, takes action by determining customer-oriented needs, design verification limits in the secondary main process can be defined as project input from the beginning. With the project level measurement of the current value flow in GC automotive companies, it can be updated according to customer needs and their positive and negative effects on the vehicle, and a standard-defined project level grade can be used under this approach in each new project (project size determination: work-timeline definition). Within the scope of this study, all design verification knowledge, which is of secondary value, can be eliminated from the customer needs in the first basic process of value creation, and instead, the orientation to common system structures can be provided. (the spread of existing base knowledge and creating lower limits on the vehicle). Providing more flexibility in the lean product development structures of GC companies will optimize the time and process losses under efficiency within the scope of the integration of two disconnected main processes in the direction of the value stream. This approach creates the cycle of just-in-time and sufficient limit information flow between the design verification steps that negatively affect the market and customer-oriented value flow of the first main structure of lean product development. In addition, in the future situation scenario that may occur within the said new cycle; in the conversion between primary and secondary main processes, a kan-ban system can be created according to the value flow. In the examinations made in the design verification steps that provide positive value conservation in the value flow, the fact that the flow step is suitable for a single discipline flow has led to the determination that the process of creating other interdisciplinary approaches must be carried out in one go (Figure 11). With the lean and value flow trainings to be carried out, project losses in interdisciplinary design verification will be reduced, and cost savings will be achieved by eliminating the intermediate disciplines within the steps, and phase transitions will be modeled in a structure more suitable for $5 \mathrm{~S}$ principles. The reorganization of the 


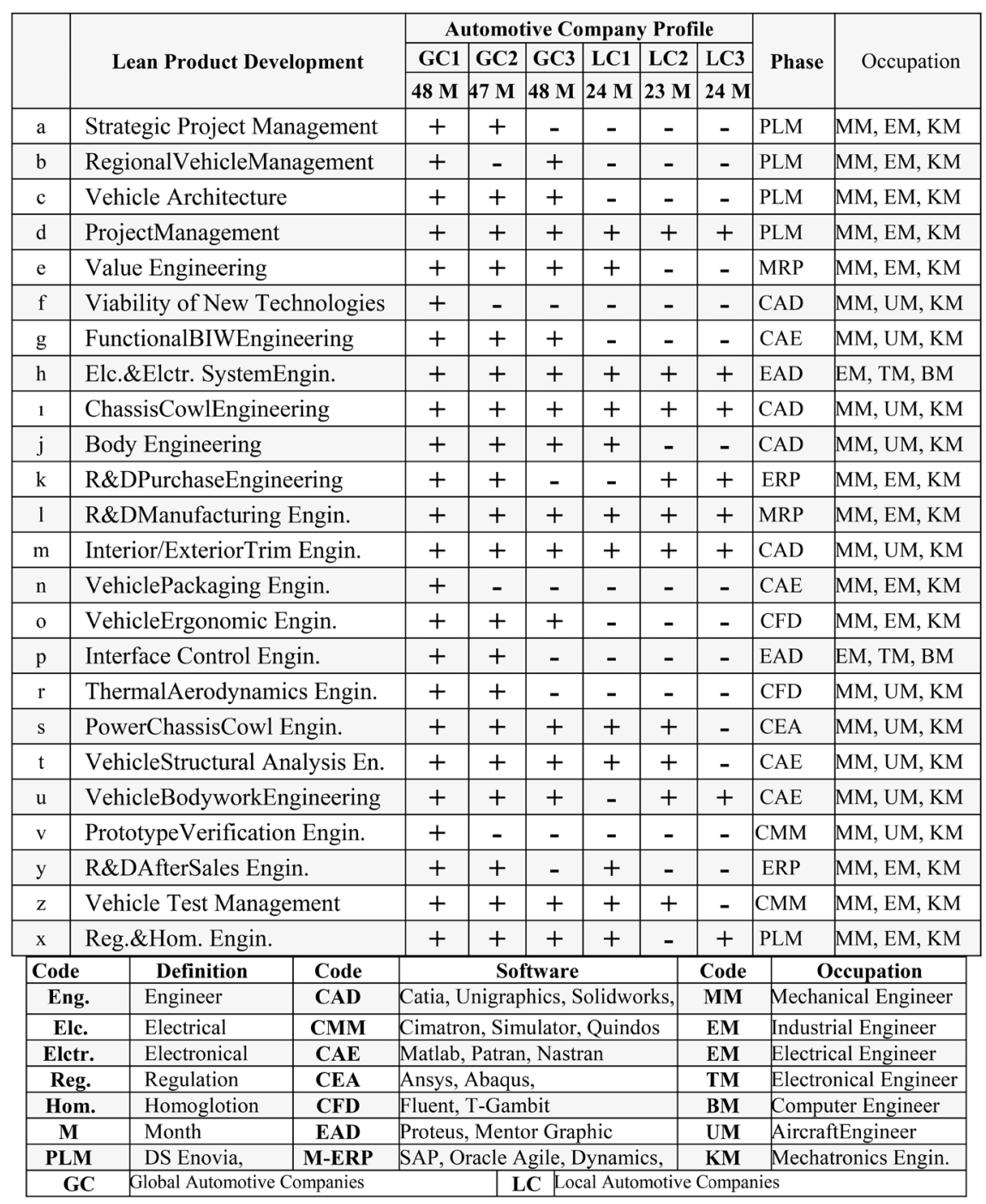

Figure 11. Lean product development in GC-LC firm with automotive design stages.

phase transitions in the lean product development processes within the framework of the kan-ban and $5 \mathrm{~S}$ principles and the design verification phase transition steps, which have a negative effect on the value flow, will make a significant contribution to the project realization time of GC automotive industry companies (Figure 11).

In the value stream in the lean product development process in LC automotive industry companies; a pull system to be created for engineering analysis with the leveling of the project mix, the project size, can minimize the design verification modification studies under the scheduling of the project goals of all other interdisciplinary common stakeholders of the automotive design activities (Figure 11). Therefore, between the design verification phase transition approval flows, the "First in First Out (FIFO)" system is established according to the project objectives, enabling continuity in the lean value flow and the cycle between steps. In addition, in the transition to the lean product development process of LC companies, collecting the interdisciplinary studies included in the 
project objectives that constitute the testing steps of the value flow, reducing the diversity in engineering analysis in the design verification step, and increasing the amount of use of this knowledge in the company, the design transformation or design speed on the piece of information it is beneficial to keep it at least at its current level (Figure 11). In this context, lean product development steps, product development disciplines are combined with automotive design activities in LC automotive industry companies, and positive value flow studies continue. By leveling the project sizes in LC companies, it can be defined with what kind of disciplines the supermarket approach can be set up in which size projects, in how long, with how many employees. According to all these data, the current new product development process becomes simpler and project levels can be revealed according to the value stream. At the same time, the product family that the lean product development team can intervene is defined.

\section{Conclusion and Recommendations}

In today's world, in the automotive sector, where borders are removed and international trade is more intense, it has become even more important for businesses to increase their competitive power. After lean production in the automotive industry, to resist increasing competition by applying lean product development process concepts, to create a value stream, to try to maintain their place in the world market with the product that comes under these innovations or to enter the world markets, constitute the basic expectations and goals of the companies participating in the research. Therefore, if automotive industry enterprises want to survive in this competitive environment, they have to learn and better implement value flow techniques with lean product development, which is currently generally accepted in the world. The study comparatively analyzed the similarities and differences at firm level under value streams with the schematic description of the lean product development flow of the case-subject minibus vehicle in GC and LC automotive industry companies.

The aim of the lean product development system is to eliminate the activities that do not add value, in other words waste, while creating and developing the new product by providing a lean value stream. For lean transformation, waste in the value streams of businesses should be revealed and eliminated. At this viewpoint, "Value Flow Management" technique is used to realize the lean transformation and to perfect it continuously. It is a very valuable tool that automotive industry businesses can use to determine where they are or where they need to go in terms of simplicity, and to enable them to transform. The implementation of value stream management will enable businesses to increase their competitiveness by making themselves leaner, and this will strengthen their position in world economies despite increasing competition.

\section{Acknowledgements}

Author (F. A. Paker) served before: Iveco Otoyol (Fiat Group), BMC, Ford Oto- 
san, Denso-Alj (Toyota group), Chevrolet (GM group), etc., automotive companies as a design and project manager for 25 years. These and other automotive company's employees, thank you for their support to the study.

\section{Conflicts of Interest}

The author declares no conflicts of interest regarding the publication of this paper.

\section{References}

[1] Paker, F.A., Alppay, C. and Sertyesilisik, B. (2018) Determination AHP Analysis of the Virtual Stage-Gate Process in the Global Scale Automotive Design. World Journal of Engineering and Technology, 6, 929-945.

https://doi.org/10.4236/wjet.2018.64062

[2] Paker, F.A., Alppay, C. and Sertyesilisik, B. (2018) Use of the AHP Methodology in Vehicle Design Process Dynamics: Determination of the Most Effective Concept Phases for the New Automotive Product. Journal of Transportation Technologies, 8, 312-330. https://doi.org/10.4236/jtts.2018.84017

[3] Paker, F.A., Alppay, C. and Sertyesilisik, B. (2018) The Pre-Republic Period of the Turkish Automotive Industry: Design and Production. Art and Design Review, 6, 185-194. https://doi.org/10.4236/adr.2018.64018

[4] Paker, F.A. (2020) The "Static" and "Dynamic" Design Verification Stages of the Lean Development Process: Automotive Industry. World Journal of Engineering and Technology, 8, 74-91. https://doi.org/10.4236/wjet.2020.81008

[5] Womack, J. and Jones, D. (1996) Lean Thinking. Simon and Schuster, New York, $1-128$.

[6] Liker, J.K. and Morgan, J. (2011) Lean Product Development as a System: A Case Study of Body and Stamping Development at Ford. Engineering Management Journal, 23, 16-28. https://doi.org/10.1080/10429247.2011.11431884

[7] Gazova, A., Papulova, Z. and Papula, J. (2016) The Application of Concepts and Methods Based on Process Approach to Increase Business Process Efficiency. Procedia Economics and Finance, 39, 197-205. https://doi.org/10.1016/S2212-5671(16)30284-2

[8] Pessôa, V.P. and Trabasso, L.G. (2017) The Lean Product Development Journey. In: The Lean Product Design and Development Journey, Springer, Cham, 141-309. https://doi.org/10.1007/978-3-319-46792-4_9

[9] Ward, A.C. and Sobek, D.K. (2014) Lean Product and Process Development. Lean Enterprise Institute Press, Cambridge, UK.

[10] Tapping, D., Luyster, T. and Shuker, T. (2002) Value Stream Management: Eight Steps to Planning, Mapping and Sustaining Lean Improvements. Productivity Inc., New York. https://doi.org/10.4324/9781482278163

[11] Emden, Z., Calantone, R. and Droge, C. (2006) Collaborating for New Product Development: Selecting the Partner with Maximum Potential to Create Value. Journal of Product Innovation Management, 23, 330-341. https://doi.org/10.1111/j.1540-5885.2006.00205.x

[12] Baysan, S. and Durmuşoğlu, M. (2015) Systematic Literature Review for Lean Product Development Principe and Tools. Sigma Journal of Engineering \& National Science, 33, 305-323.

[13] Rauch, E., Dallasega, P. and Matt, D.T. (2016) The Way from Lean Product Devel- 
opment (LPD) to Smart Product Development (SPD). Procedia CIRP, 50, 26-31. https://doi.org/10.1016/j.procir.2016.05.081

[14] Duggan, K.J. (2002) Creating Mixed Model in Value Streams. Productivity Press, New York.

[15] Song, M.J., Nam, K. and Chung, K. (2010) The Chief Executive's Influence on Corporate Design Management Activities. The Design Management Journal, 3, 32-34. https://doi.org/10.1111/j.1948-7177.2008.tb00012.x

[16] Griffin, A., Langerak, F. and Eling, K. (2018) The Evolution, Status and Research Agenda for the Future of Research in NPD Cycle Time. Journal of Product Innovation Management, 1, 1-33. https://doi.org/10.1111/jpim.12484

[17] Singer, C. (2018) Methods for Change Management in Automotive Release Processes. In: Winner, H., Prokop, G. and Maurer, M., Eds., Automotive Systems Engineering II, Springer, Cham, 31-58. https://doi.org/10.1007/978-3-319-61607-0_2

[18] Cajal, C., Santolaria, J., Acero, R. and Pueo, M. (2015) Introducing Design for Verification. Procedia Engineering, 132, 772-779.

https://doi.org/10.1016/j.proeng.2015.12.559

[19] Broch, F., Warsen, J. and Krinke, S. (2015) Implementing Life Cycle Engineering in Automotive Development as a Helpful Management Tool to Support Design for Environment. In: Sonnemann, G. and Margni, M., Eds., Life Cycle Management, Springer, Dordrecht, 319-329. https://doi.org/10.1007/978-94-017-7221-1_23

[20] Kaluza, A., Kleemann, S., Broch, F., Herrmann, C. and Vietor, T. (2016) Analysing Decision-Making in Automotive Design towards Life Cycle Engineering for Hybrid Lightweight Components. Procedia CIRP, 50, 825-830. https://doi.org/10.1016/j.procir.2016.05.029

[21] Eppinger, S.D. and Browning, T.R. (2012) Design Structure Matrix Methods and Applications. MIT Press, Cambridge, UK. https://doi.org/10.7551/mitpress/8896.001.0001

[22] Saaty, T. and Vargas, L. (1980) The Analytic Hierarchy Process. McGraw Hill, New York.

[23] Saaty, T. and Vargas, L. (2012) Models, Methods, Concepts and Applications of the Analytic Hierarchy Process. 2nd Edition, Springer, New York. https://doi.org/10.1007/978-1-4614-3597-6

[24] Ulrich, K.T. and Eppinger, S.D. (2015) Product Design and Development. McGrawHill Education, New York, 1-448.

[25] Ullah, I., Tang, D. and Yin, L. (2016) Engineering Product and Process Design Changes: A Literature Overview. Procedia CIRP, 56, 25-33. https://doi.org/10.1016/j.procir.2016.10.010

[26] Otomotiv Sanayi Derneği (2020). http://www.osd.org.tr/osd-yayinlari/osd-yayinlari/ 